\title{
Biochemical aspects of malabsorption in marasmus: effect of dietary rehabilitation
}

\author{
BY H. C. MEHTA ${ }^{1}$, A. S. SAINI ${ }^{1}$, HARJIT SINGH'2 AND P. S. DHATT ${ }^{2}$ \\ ${ }^{1}$ Department of Biochemistry and ${ }^{2}$ Department of Paediatrics, Medical College and \\ Hospital, Rohtak-124001, Haryana, India
}

(Received 20 December 1984 - Accepted 21 June 1985)

\begin{abstract}
1. Sixty marasmic children were investigated for the absorption of xylose, proteins and fats. Their duodenal juice samples were also analysed for bile salts and microflora.

2. The marasmic children were then studied in three groups of twenty by allocating them to three different dietary schedules: a high-protein diet $(30 \%$ of the total energy from protein), a high-fat diet ( $40 \%$ of the total energy from fat) and a high-carbohydrate diet ( $70 \%$ of the total energy from carbohydrate) for 2 weeks and the previous measurements repeated.

3. Whereas the high-fat diet resulted in improved fat absorption, along with an increase in total and conjugated bile acids, and the high-carbohydrate diet led to improved xylose absorption, the diet rich in protein resulted in an improvement in the absorption of all three dietary ingredients. It appears that a high-protein diet improves the overall absorption process by improving the intestinal environment as a whole, while high-carbohydrate and high-fat diets bring about adaptive changes related to the respective absorptive processes.
\end{abstract}

Malabsorption is a well-recognized phenomenon in protein-energy malnutrition (PEM) (Viteri et al. 1964) and a number of pathophysiological alterations have been described in PEM (Viteri \& Schneider, 1974). It is, however, difficult to say whether these pathophysiological alterations and malabsorption are the cause or the effect of malnutrition.

Therapeutic treatment with diets rich in proteins and energy is the most common method of management of PEM. A high-protein diet is known to improve the absorption status (Viteri et al. 1973; Stanfield, 1976) as well as pancreatic functions in PEM. A few reports on the adaptive effect of a high-fat diet on bile acids and fat absorption (Gomez et al. 1954; Schneider \& Viteri, 1974) and of a high-carbohydrate diet on pancreatic amylase (Reboud et al. 1960; Zoppi et al. 1972, 1973) are also available. However, a comprehensive study investigating separately the effects of a protein-rich, a fat-rich and a carbohydrate-rich diet on a large number of factors involved in the digestive and absorptive processes has not been undertaken. We have attempted to study this aspect in marasmic children.

\section{MATERIALS AND METHODS}

Sixty marasmic children admitted to the Paediatrics department of the Medical College, Rohtak, took part in the present study. All the children weighed less than $60 \%$ of 50 th percentile of Boston Standards (Dugdale, 1971), were in the age-range 9-42 months and free from oedema and any major infection.

These children were investigated for: (a) the absorption of proteins by studying the rise in serum proline following an oral dose of $1.5 \mathrm{~g}$ casein $/ \mathrm{kg}$ body-weight (Gould \& Schwachman, 1956); (b) the absorption of fats by studying $24 \mathrm{~h}$ faecal fat excretion (Van de Kamer et al. 1949) in twenty cases and lipiodol absorption, noting the dilution of urine positive for iodine after an oral dose of $0.5 \mathrm{ml}$ lipiodol $/ \mathrm{kg}$ body-weight (Jones \& diSant Agnese, 1963) in the remaining cases; (c) the absorption of xylose by measuring peak blood xylose level after an oral dose of $1 \cdot 1 \mathrm{~g}$ xylose $/ \mathrm{kg}$ body-weight (Roe \& Rice, 1948); (d) duodenal juice bile acids by thin-layer chromatography (Anthony \& Behar, 1964); 
Table 1. Weight, height and mid-arm circumference of marasmic children in the three groups

(Mean values and standard deviations; twenty children per group)

\begin{tabular}{|c|c|c|c|c|c|}
\hline & & Age (months) & Wt $(\mathrm{kg})$ & Height (m) & $\begin{array}{c}\text { Mid-arm } \\
\text { circumference } \\
(\mathrm{mm})\end{array}$ \\
\hline Group 1: high-protein diet & $\begin{array}{l}\text { Range } \\
\text { Mean } \\
\text { SD }\end{array}$ & $\begin{array}{l}6-36 \\
19 \cdot 4 \\
12 \cdot 6\end{array}$ & $\begin{array}{c}3 \cdot 0-8 \cdot 0 \\
5 \cdot 4 \\
1 \cdot 5\end{array}$ & $\begin{array}{c}0.55-0.80 \\
0.682 \\
0.079\end{array}$ & $\begin{array}{c}70-130 \\
91 \\
17\end{array}$ \\
\hline Group 2: high-fat diet & $\begin{array}{l}\text { Range } \\
\text { Mean } \\
\text { SD }\end{array}$ & $\begin{array}{l}8-36 \\
21 \cdot 8 \\
10 \cdot 6\end{array}$ & $\begin{array}{c}3 \cdot 5-8 \cdot 0 \\
5 \cdot 8 \\
1 \cdot 5\end{array}$ & $\begin{array}{c}0.57-0.815 \\
0.704 \\
0.082\end{array}$ & $\begin{array}{l}70-120 \\
95 \\
17\end{array}$ \\
\hline Group 3: high-carbohydrate diet & $\begin{array}{l}\text { Range } \\
\text { Mean } \\
\text { SD }\end{array}$ & $\begin{array}{l}7-42 \\
21 \cdot 6 \\
12 \cdot 0\end{array}$ & $\begin{array}{c}3 \cdot 0-9 \cdot 0 \\
5 \cdot 7 \\
1 \cdot 7\end{array}$ & $\begin{array}{c}0.56-0.85 \\
0.718 \\
0.095\end{array}$ & $\begin{array}{c}75-135 \\
93 \\
16\end{array}$ \\
\hline
\end{tabular}

Mean values were not significantly different in any case.

(e) duodenal juice microflora (aerobes) by the standard loop technique of O'Sullivan et al. (1960).

After the initial studies the children were allocated to three different dietary schedules at random in three groups of twenty each.

Group 1. Twenty children were given a high-protein $\operatorname{diet}(30 \%$ of the total energy derived from protein, $20 \%$ from fat and $50 \%$ from carbohydrate). Calcium caseinate was used as the protein supplement.

Group 2 . Twenty children were given a high-fat diet $(40 \%$ of the total energy from fat, $15 \%$ from protein and $45 \%$ from carbohydrate). Ten of these children were given fat in the form of butter and the remaining ten in the form of purified groundnut oil. Faecal fat excretion $(24 \mathrm{~h})$ was studied in all these children.

Group 3. Twenty children were maintained on a high-carbohydrate $\operatorname{diet}(70 \%$ of the total energy derived from carbohydrate, $15 \%$ from protein and $15 \%$ from fat). These children were studied under three subgroups: (a) ten children received half the carbohydrate energy as sucrose and half mainly as starch, (b) six children were given lactose instead of sucrose, (c) four children in this subgroup received only starch as the main source of carbohydrate.

The diet consisted of milk, cereals, pulses, banana, eggs and Casilan (calcium paracaseinate) as the protein supplement, butter-groundnut oil as the fat supplement and starchsucrose-lactose as the carbohydrate supplement.

All the children were given diets providing $630 \mathrm{~kJ}(150 \mathrm{kcal}) / \mathrm{kg}$ per $\mathrm{d}$. Initially a diet equivalent to about $210 \mathrm{~kJ}$ ( $50 \mathrm{kcal}) / \mathrm{kg}$ per d (or as much as a child could tolerate) was given. The diet was gradually increased to the desired amount within 5-6 d. The diets were continued for 2 weeks after which the follow-up measurements described previously were conducted. An adequate supply of minerals and vitamins was provided to all the children during the rehabilitation period.

\section{Statistical methods}

The results of different groups (before diet $v$. after diet) have been compared using the paired $t$ test, except for lipiodol absorption where the $\chi^{2}$ test has been used. For comparing the anthropometric data of children in the three groups, an unpaired $t$ test was used. 


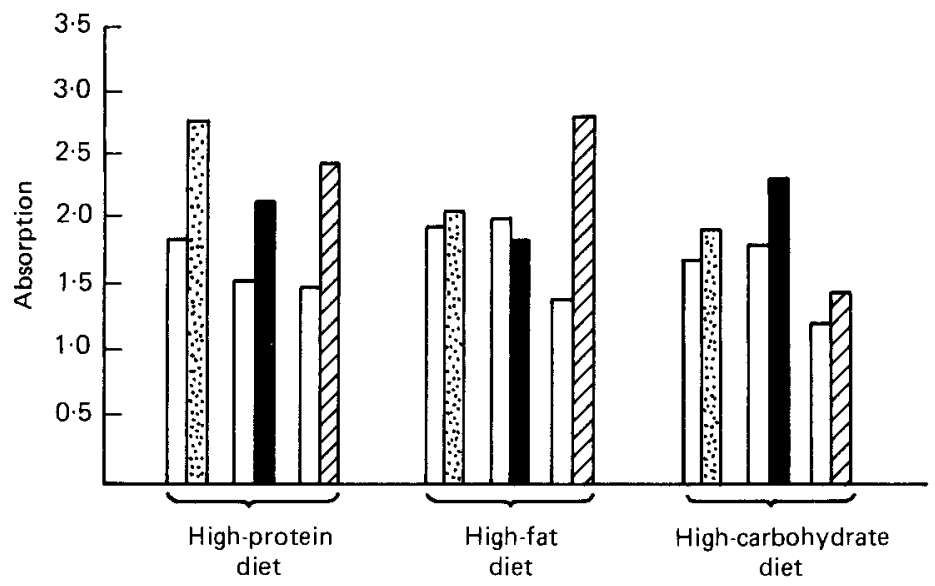

Fig. 1. Comparative effect of different diets on absorption of carbohydrates, protein and fat in marasmic children. ( $\square$ ), Before dietary therapy; (圈), rise in serum proline $(\mu \mathrm{mol} / 1 \times 0.01) ;(\square)$, peak blood xylose level $(\mathrm{mmol} / 1)$; (

Table 2. Effect of a high-protein diet on absorption in marasmic children

(Mean values and standard deviations for twenty children)

\begin{tabular}{|c|c|c|c|c|c|c|c|c|}
\hline & \multicolumn{3}{|c|}{$\begin{array}{l}\text { Protein absorption: } \\
\text { rise in serum proline } \\
(\mu \mathrm{mol} / \mathrm{l}) \text { after a casein dose }\end{array}$} & \multicolumn{3}{|c|}{$\begin{array}{c}\text { D-Xylose absorption: } \\
\text { peak blood xylose levels } \\
(\mathrm{mmol} / \mathrm{l}) \text { after a xylose dose }\end{array}$} & \multicolumn{2}{|c|}{$\begin{array}{l}\text { Lipiodol absorption: } \\
\text { urine dilution positive } \\
\text { for iodine* }\end{array}$} \\
\hline & Range & Mean & SD & Range & Mean & SD & $<1: 4$ & $>1: 4$ \\
\hline Before dietary therapy & $60 \cdot 9-382 \cdot 6$ & $191 \cdot 3$ & $87 \cdot 0$ & $0 \cdot 23-3 \cdot 33$ & 1.59 & 0.85 & 12 & 8 \\
\hline After dietary therapy & $113 \cdot 0-608 \cdot 7$ & $278 \cdot 3$ & $104 \cdot 3$ & $1 \cdot 15-4 \cdot 00$ & $2 \cdot 21$ & $0 \cdot 81$ & 5 & 15 \\
\hline $\begin{array}{l}\text { Statistical significance } \\
\text { of difference: } P<\end{array}$ & \multicolumn{3}{|c|}{0.001} & \multicolumn{3}{|c|}{0.001} & \multicolumn{2}{|c|}{0.01} \\
\hline
\end{tabular}

* Values expressed as number of cases.

\section{RESULTS}

Some difficulties were encountered in the dietary therapy experiments since many children could not tolerate the desired amount of diet as they developed diarrhoea and were excluded from the study. Generally the high-protein diet was well accepted. The high-fat diet was accepted by only $60 \%$ of the cases studied. The maximum difficulty was encountered with respect to the high-lactose diet which was tried in twenty-two cases but only six were able to tolerate it. The high-sucrose diet was initiated in sixteen cases but six of them were unable to tolerate this diet.

The weight, height and mid-arm circumference of marasmic children in the three groups are given in Table 1 . The children in the three groups did not differ significantly with respect to any of these indices $(P>0.05)$.

The effect of different diets on the absorption of different dietary ingredients is shown in Tables 2-4 and Fig. 1. The high-protein diet led to marked improvement in the absorption of proteins, xylose and lipiodol.

The high-fat diet did not result in any significant improvement in the absorption of 


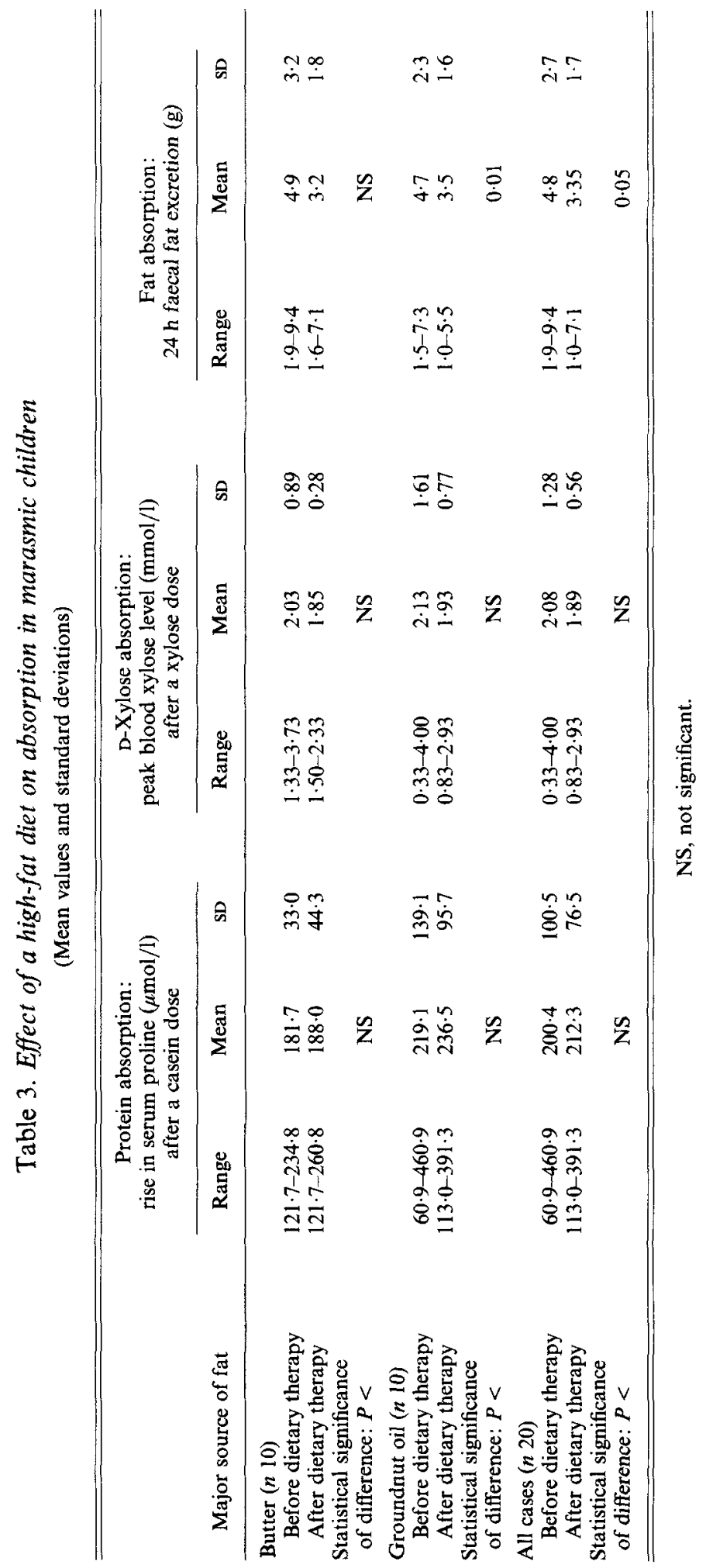




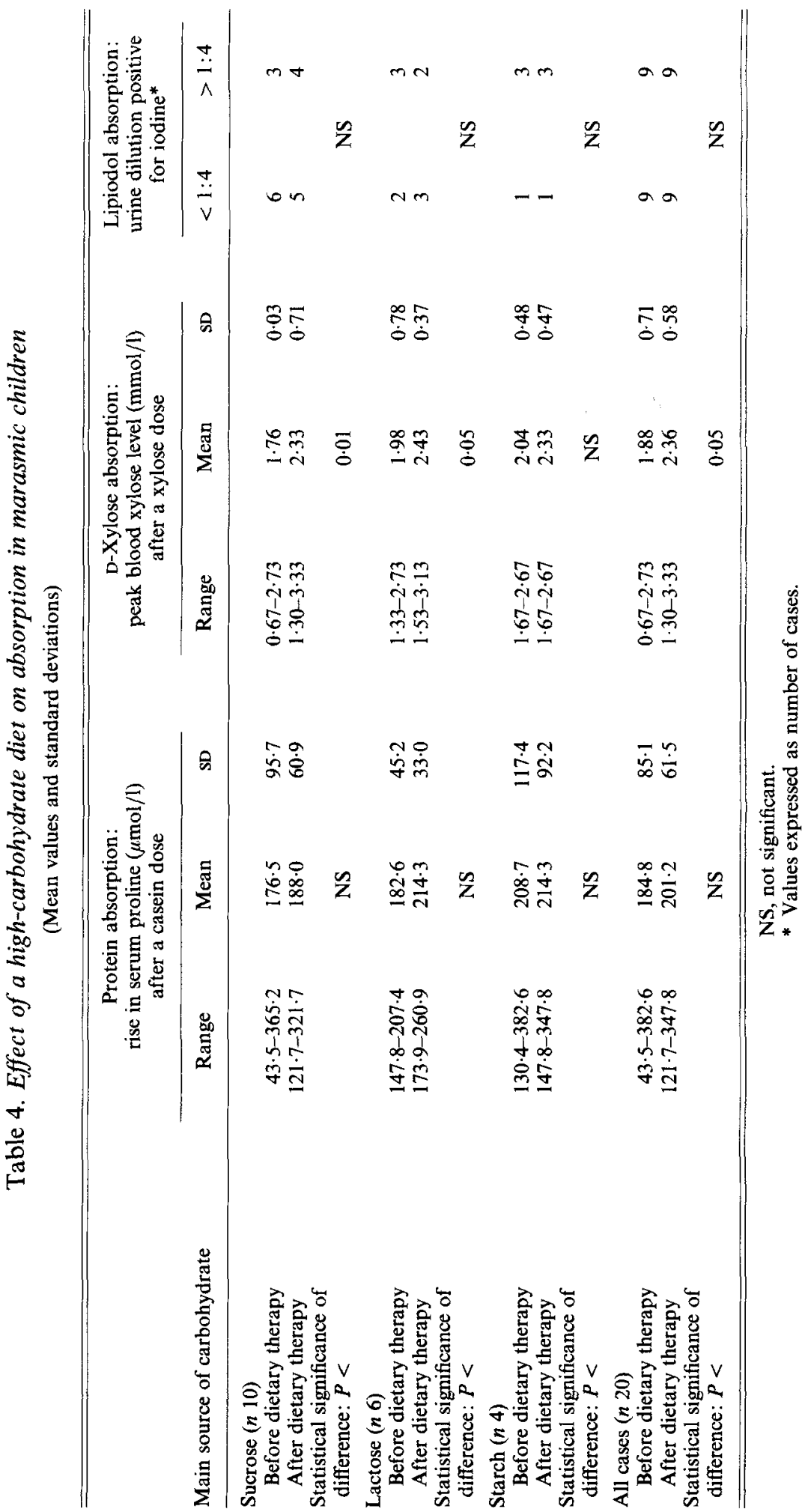


Table 5. Effect of a high-protein diet on conjugated and free bile acids in the duodenal juice samples of marasmic children

(Mean values and standard deviations for twenty children per treatment)

\begin{tabular}{|c|c|c|c|c|c|c|}
\hline & \multicolumn{3}{|c|}{$\begin{array}{l}\text { Conjugated bile acids } \\
\qquad(\mathrm{mg} / \mathrm{ml})\end{array}$} & \multicolumn{3}{|c|}{$\begin{array}{l}\text { Free bile acids } \\
\quad(\mathrm{mg} / \mathrm{ml})\end{array}$} \\
\hline & Range & Mean & SD & Range & Mean & SD \\
\hline Before dietary therapy & $0 \cdot 60-2 \cdot 60$ & 1.22 & $0 \cdot 48$ & $0 \cdot 24-1 \cdot 30$ & 0.58 & $0 \cdot 29$ \\
\hline After dietary therapy & $0 \cdot 86-3 \cdot 00$ & $1 \cdot 80$ & $0 \cdot 58$ & $0.04-0.96$ & $0 \cdot 30$ & 0.23 \\
\hline Statistical significance of difference: $P<$ & & 0.001 & & & 0.001 & \\
\hline
\end{tabular}

Table 6. Effect of a high-fat diet on conjugated and free bile acids in the duodenal juice samples of marasmic children

(Mean values and standard deviations)

\begin{tabular}{|c|c|c|c|c|c|c|}
\hline \multirow[b]{2}{*}{ Main source of fat } & \multicolumn{3}{|c|}{$\begin{array}{l}\text { Conjugated bile acids } \\
\qquad(\mathrm{mg} / \mathrm{ml})\end{array}$} & \multicolumn{3}{|c|}{$\begin{array}{l}\text { Free bile acids } \\
\quad(\mathrm{mg} / \mathrm{ml})\end{array}$} \\
\hline & Range & Mean & SD & Range & Mean & SD \\
\hline \multicolumn{7}{|l|}{ Butter $(n 10)$} \\
\hline Before dietary therapy & $0 \cdot 56-3 \cdot 20$ & 1.82 & 0.80 & $0.08-1.56$ & $0 \cdot 83$ & 0.44 \\
\hline After dietary therapy & $1 \cdot 52-4 \cdot 16$ & $2 \cdot 92$ & 1.00 & $0 \cdot 48-1 \cdot 52$ & 0.94 & 0.33 \\
\hline $\begin{array}{l}\text { Statistical significance of } \\
\text { difference: } P<\end{array}$ & & 0.001 & & & NS & \\
\hline \multicolumn{7}{|l|}{ Groundnut oil ( $n$ 10) } \\
\hline Before dietary therapy & $0 \cdot 76-3 \cdot 40$ & 1.72 & 0.79 & $0 \cdot 44-0.88$ & 0.66 & 0.14 \\
\hline After dietary therapy & $1 \cdot 04-3 \cdot 76$ & $2 \cdot 15$ & $1 \cdot 02$ & $0.44-0.96$ & 0.64 & $0 \cdot 13$ \\
\hline $\begin{array}{l}\text { Statistical significance of } \\
\text { difference: } P<\end{array}$ & & 0.02 & & & NS & \\
\hline \multicolumn{7}{|l|}{ All cases $(n 20)$} \\
\hline Before dietary therapy & $0 \cdot 56-3 \cdot 40$ & 1.77 & $0 \cdot 79$ & $0.08-1.56$ & 0.75 & 0.33 \\
\hline After dietary therapy & $1 \cdot 04-4 \cdot 16$ & $2 \cdot 54$ & 1.04 & $0 \cdot 44-1.52$ & 0.79 & 0.29 \\
\hline $\begin{array}{l}\text { Statistical significance of } \\
\text { difference: } P<\end{array}$ & & 0.01 & & & NS & \\
\hline
\end{tabular}

proteins and xylose but there was improvement in fat absorption, especially when groundnut oil was used as the source of fat. Similarly, the high-carbohydrate diet resulted in improvement in the absorption of xylose without affecting protein and fat absorption. The number of cases with an overall improved absorption status markedly increased after the high-protein diet but this was not true for other diets.

The concentration of conjugated and free bile acids in marasmic children, before and after dietary rehabilitation with different diets, is shown in Tables 5-7 and Fig. 2. The high-protein diet resulted in a significant increase in the concentration of conjugated bile acids (CBA) and a significant decline in the concentration of free bile acids (FBA) but the levels of total bile acids were not affected significantly. The high-fat diet resulted in a significant increase in the concentration of total bile acids as well as CBA but had no significant effect on the level of FBA. The high-carbohydrate diet had no significant effect on the concentration of either CBA or FBA. There was a significant decrease in the aerobes of duodenal juice after 
Table 7. Effect of a high-carbohydrate diet on conjugated and free bile acids in the duodenal juice samples of marasmic children

(Mean values and standard deviations)

\begin{tabular}{|c|c|c|c|c|c|c|}
\hline \multirow[b]{2}{*}{ Main source of carbohydrate } & \multicolumn{3}{|c|}{$\begin{array}{l}\text { Conjugated bile acids } \\
\qquad(\mathrm{mg} / \mathrm{ml})\end{array}$} & \multicolumn{3}{|c|}{$\begin{array}{l}\text { Free bile acids } \\
\quad(\mathrm{mg} / \mathrm{ml})\end{array}$} \\
\hline & Range & Mean & SD & Range & Mean & $\mathrm{SD}$ \\
\hline \multicolumn{7}{|l|}{ Sucrose $(n=10)$} \\
\hline Before dietary therapy & $0.52-2 \cdot 64$ & 1.38 & 0.74 & $0.20-0.56$ & 0.41 & $0 \cdot 12$ \\
\hline After dietary therapy & $0.92-2 \cdot 72$ & 1.66 & 0.62 & $0.32-0.60$ & 0.51 & $0 \cdot 18$ \\
\hline \multicolumn{7}{|l|}{ Lactose $(n 6)$} \\
\hline Before dietary therapy & $1 \cdot 16-2 \cdot 56$ & 1.86 & 0.47 & $0.32-0.80$ & 0.49 & $0 \cdot 18$ \\
\hline After dietary therapy & $0 \cdot 80-2 \cdot 15$ & $1 \cdot 70$ & 0.51 & $0.20-0.68$ & 0.39 & $0 \cdot 18$ \\
\hline \multicolumn{7}{|l|}{ Starch $(n 4)$} \\
\hline Before dietary therapy & $1 \cdot 50-2 \cdot 10$ & 1.75 & $0 \cdot 27$ & $0 \cdot 40-0 \cdot 65$ & 0.55 & $0 \cdot 15$ \\
\hline After dietary therapy & $1 \cdot 60-2 \cdot 20$ & 1.78 & 0.28 & $0.35-0.65$ & 0.50 & $0 \cdot 15$ \\
\hline \multicolumn{7}{|l|}{ All cases $(n 20)$} \\
\hline Before dietary therapy & $0.52-2.64$ & 1.60 & 0.60 & $0.20-0.80$ & 0.46 & $0 \cdot 14$ \\
\hline After dietary therapy & $0 \cdot 80-2 \cdot 72$ & $1 \cdot 70$ & 0.52 & $0.20-0.68$ & 0.47 & $0 \cdot 15$ \\
\hline
\end{tabular}

Mean values were not significantly different in any case.

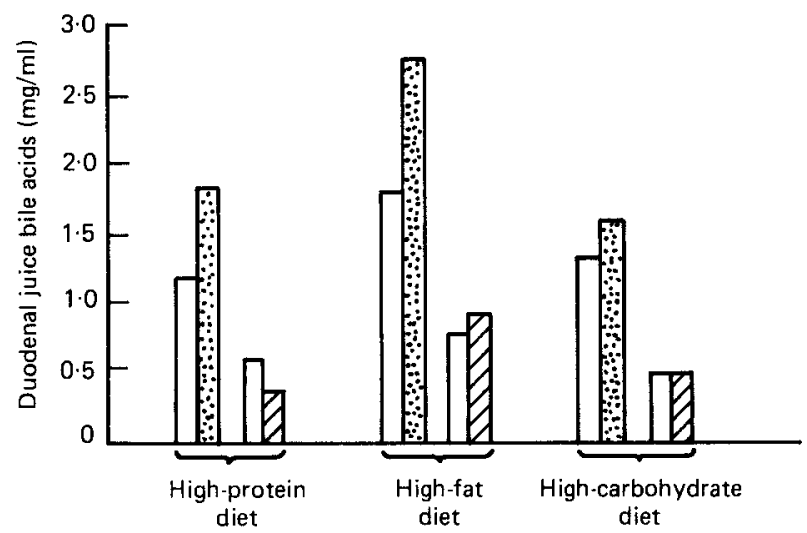

Fig. 2. Comparative effect of various diets on conjugated bile acids and free bile acids of duodenal juice of marasmic children. ( $\square$ ), Before dietary therapy; (图), conjugated bile acids; (沕) free bile acids after dietary therapy.

the high-protein diet. All fourteen cases on the high-protein diet were found to be devoid of aerobic growth in duodenal juice after dietary therapy whereas initially only six of the fourteen duodenal juice samples were sterile.

\section{DISCUSSION}

A high-protein diet is reported to improve the absorption status in malnourished children (Viteri et al. 1973) but diets rich in fat and carbohydrate affect the absorption of only fats and carbohydrates respectively (Gomez et al. 1954; Reboud et al. 1960; Schneider \& Viteri, 1974). The findings of the present study indicate that a protein-rich diet leads to an overall improvement in the absorption status of marasmic children whereas fat-rich and 
carbohydrate-rich diets improve the absorption of fats and carbohydrates respectively without any effect on the absorption of other dietary ingredients (Tables 2-4). The protein-rich diet appears to work through an overall anabolic response whereas the other diets seem to act by way of adaptation. The contention is further supported by the effect of different diets on the factors involved in digestion and absorption.

A decline in bacterial growth after therapeutic treatment with diets adequate in protein has been reported in malnourished children (Mata et al. 1972). In the present study too, the high-protein diet resulted in a significant decline in the bacterial flora of duodenal juice and the aerobic organisms completely disappeared after this diet. Such an effect, however, was not noted with any other diet.

A significant increase in the concentration of CBA has been noted after a high-fat diet. (Schneider \& Viteri, 1974). We noted a significant increase in the concentration of CBA not only with the high-fat diet but also with the high-protein diet (Tables 5 and 6). FBA, however, decreased only after the protein-rich diet. This could be because of a marked decline in micro-organisms of duodenal juice (which are known to deconjugate bile acids) after the protein-rich diet. The increase in bile acids after the high-fat diet may be attributed to increased synthesis from exogenous and endogenous cholesterol. The comparatively greater increase in bile acids with the butter-containing diet of the present study may result from the higher cholesterol content of butter compared with groundnut oil. Another possible cause of the increase in bile acids following the protein-rich and fat-rich diets may be decreased faecal loss because of improved fat absorption.

In addition to these factors the high-protein diet might also improve the functional status of mucosal cells, although morphological changes may take longer to return to normal. An improvement in pancreatic functions has also been observed after such a diet (Thompson \& Trowell, 1952; Gomez et al. 1954; Barbezat \& Hansen, 1968; Mezey \& Potter, 1976; Mehta et al. 1984a).

The present work suggests the importance of the protein-rich diet in the treatment of marasmic children. We observed delayed absorption of amino acids in the marasmic children (Mehta et al. 1984b). This could explain why the diet with a high protein content is able to induce a better anabolic response compared with diets low in protein. It is therefore suggested that marasmic children should be maintained on the high-protein diet during the initial phase of treatment after which diets with normal protein content can be used for further clinical recovery.

\section{REFERENCES}

Anthony, W. L. \& Behar, W. T. (1964). Journal of Chromatography 13, 567-570.

Barbezat, G. O. \& Hansen, J. D. L. (1968). Paediatrics 42, 77-92.

Dugdale, A. E. (1971). American Journal of Clinical Nutrition 24, 174-176.

Gomez, F., Ramos-Galven, R., Cravioto, J. \& Frenk, S. (1954). Paediatrics 13, 548-554.

Gould, B. S. \& Schwachman, H. (1956). American Journal of Diseases of Childhood 91, $584-587$.

Jones, W. O. \& diSant Agnese, P. A. (1963). Journal of Paediatrics 62, 44-49.

Mata, L. J., Jimenz, F., Cordon, M., Rosales, R., Prera, E., Schneider, R. E. \& Viteri, F. (1972). American Journal of Clinical Nutrition 25, 1118-1126.

Mehta, H. C., Saini, A. S., Singh, H. \& Dhatt, P. S. (1984a). Indian Paediatrics 21, 149-154.

Mehta, H. C., Saini, A. S., Singh, H. \& Dhatt, P. S. (1984b). British Journal of Nutrition 51, 1-6.

Mezey, E. \& Potter, J. J. (1976). Johns Hopkins Medical Journal 138, 7-12.

O'Sullivan, D. J., Fitzgerald, M. G., Meynall, M. J. \& Maline, J. M. (1960). Journal of Clinical Pathology 13, $527-528$.

Reboud, J. P., Marchis Mouren, G., Pasero, L., Cozzonne, A. \& Desnuelle, P. (1960). Biochemical Biophysical Research Communications 2, 94-99.

Roe, J. H. \& Rice, E. W. (1948). Joumal of Biological Chemistry 173, 507-512.

Schneider, R. E. \& Viteri, F. E. (1974). American Journal of Clinical Nutrition 27, 788-796.

Stanfield, J. P. (1976). In Protein Energy Malnutrition, p. 91 [G. A. O. Alleyne, R. W. Hay, D. L. Picou, J. P. Stanfield and R. G. Whitehead, editors]. London: Edward Arnold Publications. 
Thompson, M. D. \& Trowell, H. C. (1952). Lancet i, 1031-1035.

Van de Kamer, J. H., Weijers, H. A. \& Dicke, W. K. (1949). Journal of Biological Chemistry 177, 347-355.

Viteri, F., Behar, M., Arroyave, G. \& Scrimshaw, N. S. (1964). In Mammalian Protein Metabolism, vol. 2, pp. 523-568 [H. N. Munro and J. B. Allison, editors]. New York: Academic Press.

Viteri, F. E., Flores, J. M., Alvarado, J. \& Behar, M. (1973). American Journal of Digestive Diseases 18, $201-211$. Viteri, F. E. \& Schneider, R. E. (1974). Medical Clinics of North America 58, 1487-1505.

Zoppi, G., Andreotti, G., Pajno-Ferrara, F., Njal, D. M. \& Gaburro, D. (1972). Paediatric Research 6, 880-886.

Zoppi, G., Andreotti, G., Pajno-Ferrara, F., Njal, D. M. \& Gaburro, D. (1973). Paediatric Research 7, 198-203. 